Western University

Scholarship@Western

Faculty Publications

Theology

2017

\title{
Marcion's Gospel and the Resurrected Jesus of Canonical Luke 24
}

Daniel A. Smith

Huron University College, dsmith89@huron.uwo.ca

Follow this and additional works at: https://ir.lib.uwo.ca/huron_theologypub

Part of the Biblical Studies Commons, Christianity Commons, and the History of Christianity Commons

Citation of this paper:

Smith, Daniel A. "Marcion’s Gospel and the Resurrected Jesus of Canonical Luke 24." Zeitschrift für Antikes Christentum 21/1

(2017): 41-62. 


\title{
Daniel A. Smith*
}

\section{Marcion's Gospel and the Resurrected Jesus of Canonical Luke 24}

DOI 10.1515/zac-2017-0003

\begin{abstract}
New reconstructions of Marcion's Gospel, which are considerably more sophisticated than past attempts, allow more certainty when comparing Marcion's text with canonical Luke. This essay examines the presentations of the resurrected Jesus in canonical Luke and Marcion's Gospel, with a particular focus on the text-critical problems in Luke 24 (especially the shorter Western readings) and on the distinctive ways the two texts theorize Jesus' risen bodily presence

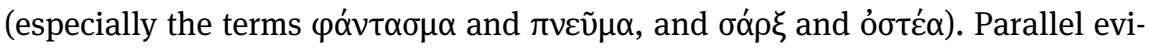
dence from the letters of Ignatius indicates that the emphasis on touching Jesus, who has risen in a flesh-and-bones body (as in Luke 24:36-43), does not reveal a specifically anti-docetic or anti-Marcionite agenda, but rather was an attempt to restrict apostolic authorization to the Twelve and their successors. These examinations provide suggestive, though admittedly not conclusive, evidence that Marcion's Gospel is the earlier text and canonical Luke the later text, particularly given the problems identifying a coherent editorial agenda on Marcion's part (assuming the priority of canonical Luke).
\end{abstract}

Keywords: Marcion, Luke, Ignatius, resurrection, flesh, spirit, phantom

Although the recent reconstructions of Marcion's Gospel ${ }^{1}$ by Jason BeDuhn, Matthias Klinghardt, and Dieter Roth differ in various ways, they agree in showing significant divergences between Marcion's Gospel and canonical Luke in the final chapter. Klinghardt poses the question as follows:

1 This term is used as shorthand for "the recension of Luke used by Marcion." See Jason D. BeDuhn, The First New Testament: Marcion's Scriptural Canon (Salem, OR, 2013); Matthias Klinghardt, Das älteste Evangelium und die Entstehung der kanonischen Evangelien (2 vols.; Texte und Arbeiten zum neutestamentlichen Zeitalter 60,1-2; Tübingen, 2015); Dieter T. Roth, The Text of Marcion's Gospel (New Testament Tools, Studies and Documents 49; Leiden, 2015). In this article, references to specific reconstructions of Marcion's Gospel are formatted according to the journal's conventions for abbreviated references to ancient primary sources (i.e. with page and line numbers and editor's last initial).

*Corresponding author: Daniel A. Smith, Faculty of Theology, Huron University College, 1349 Western Road, London, ON, N6G 1H3, Canada; e-mail: dsmith89@huron.uwo.ca 
Sind diese Differenzen zwischen dem sicher bezeugten bzw. sehr wahrscheinlichen Text, der für Mcn rekonstruiert wurde, und dem des kanonischen Lk eher Streichungen, die Marcion am kanonischen Text vorgenommen hat, oder aber Ergänzungen des vorkanonischen Evangeliums durch die lk Redaktion? ${ }^{2}$

There is, however, a third alternative, that canonical Luke represents an expansion of an earlier Vorlage which was also the ancestor text of Marcion's Gospel, which has also had a variety of supporters in the last three centuries, most recently Jason BeDuhn. ${ }^{3}$ The flexibility (or indeed instability) of the texts of the gospels in the second century is reason enough not to rule out any of these solutions from the outset. ${ }^{4}$ As Judith Lieu remarks,

Both at the macro- and at the micro-level any solution to the origins of Marcion's “Gospel” or indeed of all Gospel relationships - that presupposes relatively fixed and stable written texts, edited through a careful process of comparison, excision, or addition, and reorganisation, seems doomed to become mired in a tangle of lines of direct or indirect dependency, which are increasingly difficult to envisage in practice. Marcion's "Gospel” is to be located in the midst of these multiple trends. ${ }^{5}$

Many factors, therefore, complicate the question of the relative priority of Marcion's Gospel or canonical Luke: besides the vagaries of reconstructing Marcion's Gospel from the writings of the heresiologists, there are also significant variations in the textual tradition of canonical Luke, and problems delineating the ideological motivations behind supposed redactional activity on either side. Granted, a decision about the priority of Marcion's Gospel cannot be made on the basis of one chapter, but these issues all converge in Luke 24.

The present paper will discuss the three complicating factors just listed (namely, questions of reconstruction, text-critical witness, and purported redactional programs) as they relate to Luke 24. It proposes that Marcion's Gospel 24 represents an earlier form of the text of Luke, and canonical Luke 24 a later one,

2 Klinghardt, Das älteste Evangelium (see note 1), vol. 1, 165.

3 According to BeDuhn, First New Testament (see note 1), 78-79, 86-92 this view has had several proponents, first of all Johann S. Semler, "Vorrede," in Thomas Townsons Abhandlungen über die vier Evangelien (Leipzig, 1783), n.p.

4 See William L. Petersen, "Textual Traditions Examined: What the Text of the Apostolic Fathers Tells Us about the Text of the New Testament in the Second Century," in The Reception of the New Testament in the Apostolic Fathers (ed. Andrew F. Gregory and Christopher M. Tuckett; Oxford, 2005), 29-46. On the instability of the last three chapters of Luke, see David C. Parker, The Living Text of the Gospels (Cambridge, 1997), 148-174.

5 Judith M. Lieu, Marcion and the Making of a Heretic: God and Scripture in the Second Century (Cambridge, 2015), 208-209. 
and examines the hypothesis advanced by Klinghardt and others that the redactional program of canonical Luke 24 is best described as "anti-Marcionite." 6 It should be noted that the relative priority of Marcion's Gospel over canonical Luke does not necessarily imply a relationship of direct literary dependence between the two texts. The important question of what the priority of Marcion's Gospel might mean for the Synoptic problem will therefore be left for another study. ${ }^{7}$

\section{Reconstructing Marcion's Gospel 24: Problems and Results}

Obviously, establishing whether Marcion's Gospel is the earlier text and canonical Luke the later text depends on how reliably Marcion's Gospel can be reconstructed. As is well known, the task is complex. The Gospel is only accessible via the heresiologists, principally Tertullian and Epiphanius, who set out to refute Marcion from his own texts, the Gospel and the Apostolikon, although it is not always clear what kind of texts they possessed. ${ }^{8}$ The polemical intentions of these writers make it difficult to assess the accuracy of their quotations. The same also applies to their citation habits: as Lieu observes, Tertullian "employs a mix of summary, paraphrase, and quotation, with few indicators as to which he is using or when he is moving from one to another." 9 The heresiologists may also have

6 Matthias Klinghardt, "Markion vs. Lukas: Plädoyer für die Wiederaufnahme eines alten Falles,” New Testament Studies 52 (2006): 484-513 (though without reference to Luke 24); Klinghardt, Das älteste Evangelium (see note 1), vol. 1, 171; see also Joseph B. Tyson, Marcion and LukeActs: A Defining Struggle (Columbia, SC, 2006), 108-109. On the production of the canonical New Testament as a response to Marcion, see Markus Vinzent, Marcion and the Dating of the Synoptic Gospels (Studia Patristica Supplements 2; Leuven, 2014), 279-282.

7 For recent work on this question, see Matthias Klinghardt, "The Marcionite Gospel and the Synoptic Problem: A New Suggestion,” Novum Testamentum 50 (2008): 1-27; Judith M. Lieu, "Marcion and the Synoptic Problem," in New Studies in the Synoptic Problem: Essays in Honour of Christopher M. Tuckett (ed. Paul Foster et al.; Bibliotheca Ephemeridum Theologicarum Lovaniensium 239; Leuven, 2011), 731-751; BeDuhn, First New Testament (see note 1), 92-97; Vinzent, Marcion (see note 6), 213-214, 255-276; Klinghardt, Das älteste Evangelium (see note 1), vol. 1, 181-347.

8 For a brief discussion of the sources and a comprehensive listing of verses attested for Marcion's Gospel, see Roth, Marcion's Gospel (see note 1), 46-78. On Tertullian's text of Marcion's Gospel, see also Dieter T. Roth, "Did Tertullian Possess a Greek Copy or Latin Translation of Marcion’s Gospel?,” VigChr 63 (2009): 429-467; Klinghardt, Das älteste Evangelium (see note 1), vol. 1, 67-71.

9 Lieu, Marcion (see note 5), 191. 
been influenced in many instances by their own familiarity with Synoptic parallels, so that the origin of harmonizing readings in citations of Marcion's Gospel is not always clear. ${ }^{10}$ In addition, Tertullian often passes over in silence passages that Epiphanius later claims Marcion excised from canonical Luke, even though both assert, following Irenaeus, that Marcion mutilated (that is, edited mainly by deletion) the Gospel of Luke. ${ }^{11}$ Finally, there are the curious instances in which Tertullian criticises Marcion for cutting out of Luke material which is not actually found in Luke, for example, Matt 5:17. ${ }^{12}$

Given these and other complicating factors, the three most recent reconstructions of Marcion's Gospel display varying levels of precision and caution, although BeDuhn, Roth, and Klinghardt are all clear about both their goals and methods. BeDuhn states that "even though in many cases fairly reliable conclusions" about the original Greek wording are possible, the English translation signals that his reconstruction "should be considered an approximation of the original."13 Along similar lines, Roth does not attempt "to reconstruct any supposed 'original text' of Marcion's Gospel” but rather "to provide the most accurate possible reconstruction of Marcion's Gospel based upon the attestation of the sources that contain the evidence for the readings found in it." ${ }^{14}$ This means that Roth generally will not argue that an unattested passage was absent from Marcion's Gospel. Klinghardt attempts to reconstruct the Greek text of Marcion's Gospel, but like Roth and BeDuhn he acknowledges that a precise text is out of reach. ${ }^{15}$ As the reconstructions all show, however, relative precision and moderate confidence are possible in certain cases. Both Roth and Klinghardt print their reconstructed Greek text in different typefaces to show degrees of certainty about

10 Lieu, Marcion (see note 5), 199-200; Roth, Marcion's Gospel (see note 1), 438-439.

11 Lieu, Marcion (see note 5), 198-199, indicating that for the heresiologists this could include both excision and changes to wording. For Marcion as mutilator of canonical Luke, see Irenaeus, Adversus Haereses 1,27,2 (SC 264, 350,19-28 Rousseau/Doutreleau); Tertullian, Adversus Marcionem 4,2,4 (SC 456, 70,25-28 Moreschini/Braun); Epiphanius, Panarion 42,9,1-2 (GCS 31, 104,22-105,4 Holl/Dummer). Roth, Marcion's Gospel (see note 1), 75-76 lists the passages passed over in silence by Tertullian, but noted by Epiphanius as absent.

12 Jason BeDuhn, “The Myth of Marcion as Redactor," Annali di Storia dell' Esegesi 29 (2012): (21-48) 24; see also David S. Williams, "Reconsidering Marcion's Gospel," Journal of Biblical Literature 108 (1989): (477-496) 480; Dieter T. Roth, "Matthean Texts and Tertullian's Accusations in Adversus Marcionem,” JThS 59 (2008): 580-597. See, for example, Tertullian, Adversus Marcionem 4,7,4 (SC 456, 96,38-40 M./B.).

13 BeDuhn, First New Testament (see note 1), 53.

14 Roth, Marcion's Gospel (see note 1), 4.

15 Klinghardt, Das älteste Evangelium (see note 1), vol. 2, 449. 
the reconstruction, but only Klinghardt prints all of canonical Luke in each pericope attested for Marcion's Gospel, in order to indicate the differences clearly. ${ }^{16}$

All three scholars reconstruct Marcion's Gospel without appealing to Marcion's theological tendencies and supposed editorial program-a particular weakness of Adolf von Harnack's work. ${ }^{17}$ BeDuhn and more especially Roth use a similar approach to that used by Ulrich Schmid in his reconstruction of Marcion's Apostolikon: they evaluate the heresiologists' citations of Marcion's Gospel on the basis of a careful description of "their general handling of texts throughout their corpus, based on multiple citations." 18 An implication of this for Roth is that "an initial reconstruction ... must resist the temptation to draw firm conclusions concerning the unattested passages." ${ }^{19}$ Roth discusses passages in Marcion's Gospel in chapters devoted to the tendencies of the sources, rather than in the context of a running reconstruction of Marcion's Gospel (as BeDuhn and Klinghardt do).

Examples from Marcion's Gospel 24:1-11, the Empty Tomb scene, illustrate the different tendencies of the three reconstructions. Klinghardt undertakes his reconstruction from the perspective of the priority of Marcion's Gospel. ${ }^{20}$ According to Klinghardt, an important methodological insight arises from the contact between Marcion's Gospel as directly attested by the heresiologists and the variant readings of canonical Luke. "Dies nötigt $\mathrm{zu}$ der methodischen Einsicht einer wechselseitigen Interdependenz von Text- und Literarkritik." ${ }^{21}$ Klinghardt's reconstruction of Marcion's Gospel 24 therefore often follows the variant readings in canonical Luke 24 , especially Western readings (attested mainly in Codex Bezae and Old Latin manuscripts), sometimes even against the explicit citations, or silence, of the heresiologists. ${ }^{22}$ A group of shorter Western readings

16 Roth, Marcion's Gospel (see note 1), 410-412; Klinghardt, Das älteste Evangelium (see note 1), vol. 2, 450-453.

17 BeDuhn, First New Testament (see note 1), 47-50; Roth, Marcion's Gospel (see note 1), 81; Klinghardt, “Markion vs. Lukas” (see note 6), 496. Klinghardt's affirmation of the priority of Marcion's Gospel obviously excludes the idea of Marcion editing Luke: idem, Das älteste Evangelium (see note 1), vol. 1, 117-141, 351-362.

18 Roth, Marcion's Gospel (see note 1), 79; see Ulrich Schmid, Marcion und sein Apostolos: Rekonstruktion und historische Einordnung der marcionitischen Paulusbriefausgabe (Arbeiten zur neutestamentlichen Textforschung 25; Berlin, 1995), 26-29. See also BeDuhn, First New Testament (see note 1), 48, 53-54.

19 Roth, Marcion's Gospel (see note 1), 81 (note 88).

20 Klinghardt, Das älteste Evangelium (see note 1), vol. 1, 117-141, 351-362.

21 Klinghardt, Das älteste Evangelium (see note 1), vol. 1, 358; for his estimation of the importance of the Western witnesses, see 73-78.

22 Codex Bezae (D 05 [gr.] and d 5 [lat.]): Cambridge, University Library, Nn. 2. 41. See e. g. Mar-

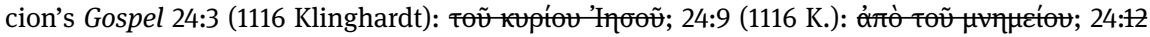


in canonical Luke 24, Brooke F. Westcott and Fenton J. A. Hort's "Western non-interpolations," which generally are not attested in the heresiologists, are given high regard in Klinghardt's reconstruction of Marcion's Gospel $24 .{ }^{23}$ However, Klinghardt also follows longer Western variants: for example, he proposes the

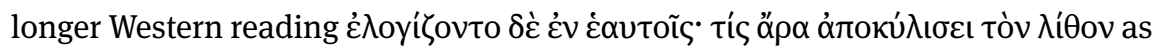
“wahrscheinlich” for Marcion's Gospel 24:1, even though it is not attested by the heresiologists. ${ }^{24}$ This makes one wonder what might exclude a variant reading from consideration by Klinghardt as the original wording of Marcion's Gospel.

BeDuhn and Roth also pay close attention to the variant readings in canonical Luke 24, but BeDuhn tends to be more cautious than Klinghardt in following the unattested shorter Western readings, and Roth is very reticent. ${ }^{25}$ Roth prefers to say of these unattested readings only that they are unattested, including the difficult v. $12 .{ }^{26}$ BeDuhn, however, tends to highlight readings that do not harmonize Luke to Matthew: "[t]he Evangelion has substantially fewer (one third) of the

(1116 K.). Klinghardt claims that Tertullian's copy of Marcion’s Gospel had already been "kontaminiert" in this passage by the "kanonischen Mehrheitstext" through the addition of material such as the longer reading found in Marcion's Gospel 24:9: Klinghardt, Das älteste Evangelium (see note 1), vol. 2, 1123; on canonical Luke 24:12: ibid., 1128-1130. Concerning the shorter Western readings, see below, Section 2 .

23 Brooke F. Westcott and Fenton J. A. Hort, The New Testament in the Original Greek 2 (New York, 1882), 295; Klinghardt, Das älteste Evangelium (see note 1), vol. 1, 73-93.

24 Marcion's Gospel 24:1b [attested for Marcion's Gospel but not present in canonical Luke] (1116 K.). Klinghardt, Das älteste Evangelium (see note 1), vol. 2, 1118 thinks the sentence, which parallels Mark 16:3, illustrates Markan dependence on Marcion's Gospel; see also Vinzent, Marcion (see note 6), 274. The longer variant of canonical Luke 24:1 is found in D $070 \mathrm{c}$, and this is the only "attestation" for the sentence's presence in Marcion's Gospel; cf. the critical apparatus of NA ${ }^{28}$ (Barbara and Kurt Aland et al., eds., Novum Testamentum Graece [28th rev. ed.; Stuttgart, 2014], 286). New Testament manuscripts are abbreviated according to this edition.

25 Contrast, for example, Marcion’s Gospel 24:9 (126 BeDuhn) with 24:3 (435 Roth). On ámò toṽ $\mu v \eta \mu \varepsilon i ́ o v$ as present in Marcion's Gospel 24:9, BeDuhn writes, “although [Western witnesses] omit 'from the tomb,' the Evangelion apparently had it, unless Tertullian is supplying it in paraphrase" (First New Testament [see note 1], 194); see Marcion's Gospel 24:9 "from the tomb"

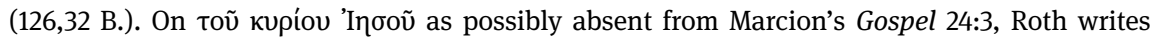
that this "cannot be substantiated by Tertullian's silence” (Marcion’s Gospel [see note 1], 266 [note 423]); see Marcion's Gospel 24:3 toṽ kupíou 'Inбoṽ [unattested] (435 R.).

26 Marcion's Gospel 24:12 [unattested] (435 R.). Roth, Marcion's Gospel (see note 1), 26 says that Harnack “created evidence” for Marcion's Gospel by asserting that the unattested Luke 24:12 had been excised by Marcion. Cf. Adolf von Harnack, Marcion: Das Evangelium vom fremden Gott: Eine Monographie zur Geschichte der Grundlegung der katholischen Kirche (2d ed.; TU 45; Leipzig, 1924), $238^{\star}$. 
'minor agreements' accepted in the critical text of Luke." ${ }^{27}$ For example, BeDuhn states that “in v. 6 the Evangelion apparently read 'he was awoken' (Epiphanius) in agreement with Mark, rather than 'he is not here, but was awoken' in agreement with Matthew," although Mark actually has both clauses, just in the reverse

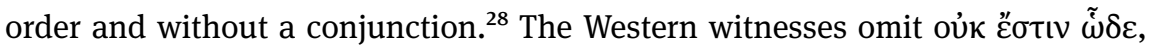
$\dot{\alpha} \lambda \lambda^{\prime}$ ’ $\gamma^{\prime} \rho \theta \eta \eta$ in v. 6, so Klinghardt excludes the whole line from Marcion's Gospel, claiming that Epiphanius's copy of Marcion's Gospel had been corrupted here by the canonical text. ${ }^{29}$ Roth, on the other hand, argues convincingly that n’ý$\rho \theta \eta$ is

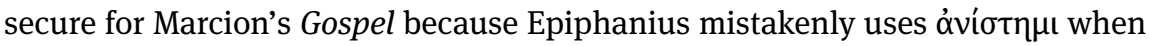
quoting this verse elsewhere. ${ }^{30}$ BeDuhn's reconstruction of Marcion's Gospel 24:4 also shows his interest in non-harmonizing readings: He proposes "in shining

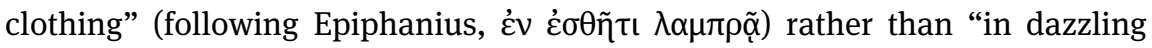

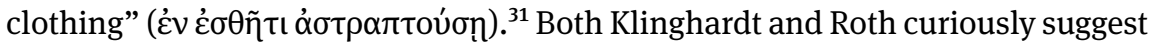

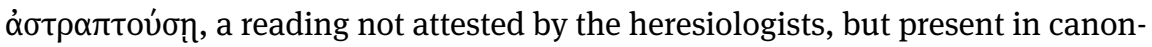
ical Luke. ${ }^{32}$ However, BeDuhn is correct that "the minor agreement between Matthew and Luke ... was not present in the Evangelion." 33

Further study might reveal other tendencies of the three latest reconstructions, but these examples illustrate that working with Marcion's Gospel requires consulting all three on a case-by-case basis and evaluating their readings (or their reluctance to offer readings) as well as the supporting evidence. In the present study, however, the reconstructions generally agree on the most important differences between Marcion's Gospel 24 and canonical Luke 24 for assessing both the relative priority of the two recensions and the theological agendas present in their composition and/or redaction.

27 BeDuhn, First New Testament (see note 1), 93. The term "minor agreements" refers to agreements of Matthew and Luke against Mark in Triple Tradition passages, which BeDuhn sees as scribal harmonizations of Luke to Matthew.

28 BeDuhn, First New Testament (see note 1), 194; Marcion's Gospel 24:6 (126 B.): "he was

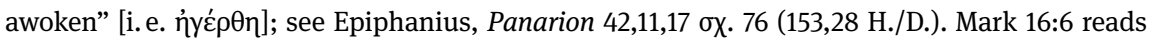

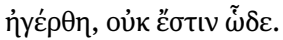

29 Marcion's Gospel 24:6 (1116 K.): älteste Evangelium (see note 1), vol. 2, 1119.

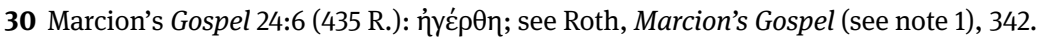

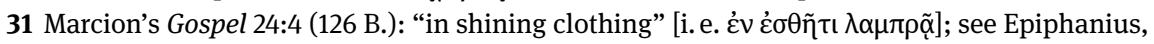

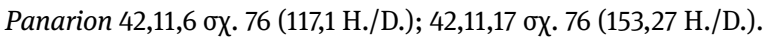

32 Marcion's Gospel 24:4 (1116 K.; 435 R., rated "possible" though the precise wording is unat-

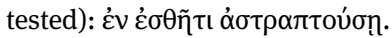

33 BeDuhn, First New Testament (see note 1), 194. 


\section{Luke 24 and the Shorter Western Readings}

Seven of nine of Westcott and Hort's "Western non-interpolations"-the shorter Western readings they considered original-are found in Luke $24 .{ }^{34}$ Generally, twentieth-century textual critics tended to see the shorter readings as secondary omissions, primarily because of the weight given to $\mathrm{P}^{7535}$ as a witness to Luke. ${ }^{36}$ Some now take the older view again that the longer readings are secondary: Bart Ehrman, for example, thinks that "these secondary corruptions of which the Western tradition is innocent all work in the same direction: each functions to counter the docetic Christologies that can be dated to the time of their creation, the early to mid-second century." ${ }^{37}$ The claim that the longer readings are all antidocetic does not stand up to close scrutiny. ${ }^{38}$ However, Ehrman does raise the question whether they should be assessed individually or as a group. While some textual critics advocate a thoroughgoing eclecticism in which each of these variants is considered separately, Wade Martin has shown how unlikely it is that these readings did not share a common origin, even if there might not have been a single motivation (as Ehrman suggested) for addition or deletion across the various instances. ${ }^{39}$

As already noted, these shorter Western readings in canonical Luke 24 seem to align with Marcion's Gospel, but to be more precise, the longer readings are generally not attested by Tertullian and Epiphanius as present in (or absent

34 Westcott and Hort, New Testament 2 (see note 23), 175-177, 295.

$35 \mathrm{P}^{75}$ : Vatican, Papyrus Bodmer XIV. XV.

36 Bruce M. Metzger, A Textual Commentary on the Greek New Testament (2d ed.; Stuttgart, 1994), 164-166.

37 Bart D. Ehrman, The Orthodox Corruption of Scripture: The Effect of the Early Christological Controversies on the Text of the New Testament (New York, 1993), 221. See also Mikeal C. Parsons, “A Christological Tendency in P75," Journal of Biblical Literature 105 (1986): 463-479; Michael W. Martin, "Defending the 'Western Non-Interpolations': The Case for an Anti-Separationist Tendenz in the Longer Alexandrian Readings," Journal of Biblical Literature 124 (2005): 269-294; Tim Carter, “Marcion's Christology and Its Possible Influence on Codex Bezae,” JThS 61 (2010): 550-582.

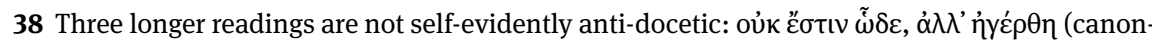

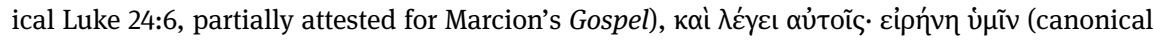

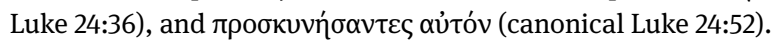

39 See James K. Elliott, “The Case for Thoroughgoing Eclecticism,” in Rethinking New Testament Textual Criticism (ed. David A. Black; Grand Rapids, MI, 2002), (101-124) 116; cf. Martin, "Defending" (see note 37), 276-278. This causes a serious problem for the view that the shorter readings are straightforwardly Marcionite deletions of the longer (original) text of Luke, as proposed by Carter, "Marcion's Christology" (see note 37), 566-574. 
from) Marcion's text. ${ }^{40}$ Yet this does not only apply to these shorter readings: by Klinghardt's count, nearly two-thirds of the readings attested for Marcion's Gospel that diverge from canonical Luke are also found in one or more Western witnesses. ${ }^{41}$ This has led many, most influentially Adolf von Harnack, to think Marcion's Gospel was based on the Western recension of Luke, given that Marcion's text has many Western readings that harmonize to Matthew or Mark. ${ }^{42}$ However, Roth notes that it is often unclear whether such harmonizations originate with Marcion or the authors who cite him. ${ }^{43}$ As to Westcott and Hort's Western non-interpolations, in two cases, canonical Luke 22:19b-20 and 24:6, the non-Western longer readings are partially or possibly attested for Marcion's Gospel, and in a third case, canonical Luke 24:9, the non-Western longer reading is clearly attested for Marcion's Gospel. ${ }^{44}$ At the very least, the uneven agreement between Marcion's Gospel as attested in the heresiologists and the Western text of canonical Luke should warn against a straightforward acceptance of Western readings as evidence for Marcion's Gospel. When Tertullian and Epiphanius have readings for Marcion's Gospel that disagree with the Western witnesses for Luke, however, Klinghardt prefers the Western reading for Marcion's Gospel, asserting that the heresiologists' copies of Marcion's Gospel were at these points corrupted by the "kanonischen Mehrheitstext." 45 This mode of appeal is made possible by-but also supports-Klinghardt's position that Marcion's Gospel was the first gospel. ${ }^{46}$

Of all the longer non-Western readings in canonical Luke 24, the most important for the presentation of the resurrected Jesus is v. 12. If Tertullian or Epiphanius had thought that Marcion had deleted this verse, which narrates Peter's apostolic confirmation of the empty tomb and discovery of the grave-clothes, they probably would have said something; but neither seems to know this verse at

40 See Roth, Marcion's Gospel (see note 1), 75-76, for verses attested as not present in Marcion's Gospel.

41 Klinghardt, Das älteste Evangelium (see note 1), vol. 1, 73 (329 out of 528).

42 Harnack, Marcion (see note 26), 242*-243*.

43 Roth, Marcion's Gospel (see note 1), 439.

44 Dieter T. Roth, "Marcion and the Early New Testament Text," in The Early Text of the New Testament (ed. Charles E. Hill and Michael J. Kruger; Oxford, 2012), (302-312) 311. See Marcion's Gospel 22:19-20 (433 R.), with support for part of v. 20 in Tertullian, Adversus Marcionem 4,40,4

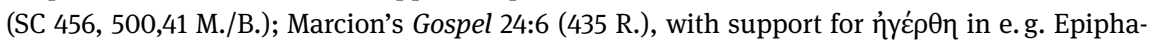
nius, Panarion 42,11,17 ox. 76 (153,28 H./D.); and Marcion's Gospel 24:9 (435 R.), with support for

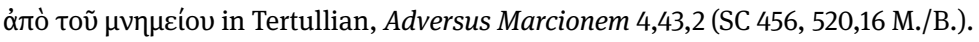

45 Thus Klinghardt, Das älteste Evangelium (see note 1), vol. 2, 1123, on following the shorter Western reading against Tertullian in reconstructing Marcion's Gospel 24:9 (1116 K.).

46 Klinghardt, Das älteste Evangelium (see note 1), vol. 1, 78-85. 
all. ${ }^{47}$ In fact, no Christian author before Ambrose refers to canonical Luke 24:12.48 Lieu and Klinghardt are in my judgment correct to conclude that the verse was not in Marcion's Gospel, but Roth will only say that it is "unattested." ${ }^{49}$ The question of the verse's origin is complicated by verbal parallels in John 20:3-10: besides the historical present $\beta \lambda \varepsilon \dot{\tau} \tau \varepsilon$, there are also the Lukan hapaxes $\pi \alpha \rho \alpha \kappa u ́ \pi \tau \omega$ and

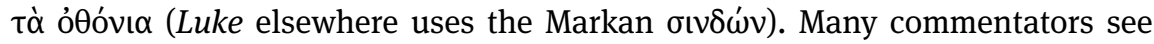
these verbatim agreements as additional evidence that the verse is secondary to canonical Luke, particularly because two other longer non-Western readings in canonical Luke 24 also show close similarities to John (namely, Luke 24:36b.40). These verses are also not attested for Marcion's Gospel. ${ }^{50}$ However, others, myself included, have found the indications of Lukan style in canonical Luke 24:12 to be compelling, though not incontrovertible, evidence for its originality. ${ }^{51}$ Canonical Luke 24:24, which is present in Western witnesses but not attested for Marcion's Gospel, describes a second visit to the tomb confirming the women's discovery that would make little sense without v. 12, but its plural might also show the sec-

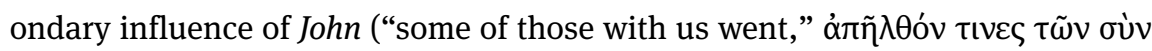

47 In view of the content of canonical Luke 24:12, it is surprising that Carter can conclude that "the failure of Tertullian and Epiphanius to mention passages that Marcion has deleted cannot be taken as evidence that Marcion had not removed them: it only means that they were not included in their account because they could not be used against him" (Carter, "Marcion's Christology" [see note 37], 570).

48 Ambrose, Expositio Euangelii secundum Lucam 10,174 (SC 52, 214 Tissot) actually conflates Luke with John, supposing that Peter returned to the tomb a second time alone.

49 Marcion’s Gospel 24:12 (1116 K.); 24:12 [unattested] (435 R.). See Lieu, Marcion (see note 5), 218; Klinghardt, Das älteste Evangelium (see note 1), vol. 2, 1130; cf. Roth, Marcion's Gospel (see note 1), 26 (note 112), 78; idem, "Early New Testament Text” (see note 44), 310-311. BeDuhn, First New Testament (see note 1), 195 states that verse 12 “is unattested [for Marcion's Gospel], generally thought to be secondary in Luke.” His reconstruction omits the verse (Marcion's Gospel 24:12 [126 B.]).

50 Roth, Marcion's Gospel (see note 1), 78.

51 For Luke 24:12 as original, see Frans Neirynck, "Luke 24,12: An Anti-Docetic Interpolation?," in New Testament Textual Criticism and Exegesis: Festschrift J. Delobel (ed. Adelbert Denaux; Bibliotheca Ephemeridum Theologicarum Lovaniensium 161; Leuven, 2002), 145-158 (only one of several of Neirynck's studies of the problem); Odette Mainville, "De Jésus à l'Église: étude rédactionelle de Luc 24,” New Testament Studies 51 (2005): (192-211) 197-198; Daniel A. Smith, Revisiting the Empty Tomb: The Early History of Easter (Minneapolis, 2010), 115-118. For the verse as secondary, see Anton Dauer, “Zur Authentizität von Lk 24,12,” Ephemerides Theologicae Lovanienses 70 (1994): 294-318; Parker, Living Text (see note 4), 167-168; Tyson, Marcion and Luke-Acts (see note 6), 103-104; Ehrman, Orthodox Corruption (see note 37), 212-217. 
$\dot{\eta} \mu \tilde{v})$. The latter verse is present in Western witnesses but unattested for Marcion's Gospel. ${ }^{52}$

What purpose does Luke 24:12 serve in the context of the canonical form of the chapter? Sometimes commentators suggest that the verse provides male confirmation of the empty tomb where female testimony would have been considered inadequate or inadmissible in Judean culture. ${ }^{53}$ Carolyn Osiek, however, argues persuasively that this is not as certain as some exegetes often assume, and that in private and domestic affairs, which would include burial and mourning, women could function as witnesses. ${ }^{54}$ In my opinion, v. 12 only makes sense in connection with the announcement in v. 34 (also not attested for Marcion's

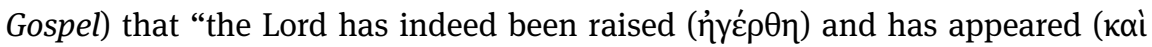
$\omega \varphi \theta \eta)$ to Simon," a line almost certainly dependent on 1 Cor 15:5.55 This cannot refer to Peter's inspection of the tomb, for he did not see the resurrected Jesus (see also canonical Luke 24:24). Together, however, canonical Luke 24:12 and 24:34 restrict both the interpretation of the resurrection appearances and their authorizing power. When Peter, the primary resurrection witness, finds the tomb empty except for the graveclothes, this can only mean that the resurrected Jesus appeared to him, not in a visionary mode, but in the flesh. The addition of the graveclothes shows an apologetic interest in clarifying the meaning of the empty tomb, which otherwise could be open to varying interpretations. However, the issue is not specifically the reality of the resurrection appearances, but rather the restriction of apostolic authorization and enlightenment to those who witnessed the resurrected Jesus in the flesh, specifically the Twelve. ${ }^{56}$ As I argued in two previous contributions, these pieces are part of a larger redactional and theological schema in canonical Luke 24 that is only fully clarified through the

52 Marcion's Gospel 24:24 [unattested] (435 R.); [unattested but probably absent] (127 B.; 1131 K.). BeDuhn, First New Testament (see note 1), 195 says that the whole passage (canonical Luke 24:21b-24) "appears to be a summary of John 20.1-10 rather than of the Lukan narrative." 53 Scholars often cite Josephus, Antiquitates judaicae 4,8,15 (ed. Étienne Nodet, Flavius Josèphe, Les antiquités juives 2: Livres IV et $V$ [Paris, 1995], 61*-62^). See e. g. François Bovon, Luke 3: A Commentary on the Gospel of Luke 19:28-24:53 (Hermeneia; Minneapolis, 2012), 353: "the fragile testimony of the women received a more reliable confirmation through a man."

54 Carolyn Osiek, “The Women at the Tomb: What Are They Doing There?," Ex auditu 9 (1993): (97-107) 103-104.

55 Marcion's Gospel 24:34 [unattested] (435 R.); [unattested but probably absent] (127 B.; 1131 K.). 56 Smith, Revisiting (see note 51), 103-108; idem, "Seeing a Pneuma[tic Body]: The Apologetic Interests of Luke 24:36-43,” Catholic Biblical Quarterly 72 (2010): (752-772) 765-771. For a full discussion, see Shelly Matthews, "Fleshly Resurrection, Authority Claims, and the Scriptural Practices of Lukan Christianity,” Journal of Biblical Literature 136 (2017): 163-183. 
narration of the flesh-and-bones appearance to the circle of the Eleven (canonical Luke 24:36-43), the focus of the final section of this paper. ${ }^{57}$

Recent work on the relative priority of Marcion's Gospel over canonical Luke, however, suggests that this Lukan redactional and theological schema is actually better described in relation to the canonical form of the gospel, rather than its original composition. Of course, it has long been debated whether the early Christian heresiologists were right that Marcion edited canonical Luke in order to produce his gospel. ${ }^{58}$ The main argument against the traditional view is that Marcion's Luke, once reconstructed, fails to display a coherent editorial agenda: as BeDuhn writes, “[t]he 'missing' material relative to Luke does not contain any concept contrary to Marcionism not found also in other passages retained in the Evangelion. A number of themes and ideas found in it flatly contradict the developed Marcionite ideology known to us." ${ }^{59}$ In one famous passage, Tertullian even accuses Marcion of plotting to leave in material he might have been expected to excise, in order to trick readers into thinking he did not take anything out. ${ }^{60}$

In light of this lack of a consistent editorial agenda, it seems best to suppose that Marcion did not choose Luke from the four gospels as the best one to abridge to his own purposes, but simply used the one that he had. Although it is probable that Marcion did adapt this text to his own needs-as evidently was common in the second century-it was only to later readers using canonical Luke that Marcion's Gospel seemed to be an abridgement of it. BeDuhn's additional observation, that canonical Luke and Marcion's Gospel tend to display independent patterns of harmonization, ${ }^{61}$ might provide further confirmation of this, or of the theory that Marcion's Gospel and canonical Luke should be viewed as independent recensions of a common Vorlage, a kind of Proto-Luke; but evaluating this is beyond the scope of this essay. ${ }^{62}$ Also difficult to evaluate are Markus Vinzent's claims that a complex set of Marcion's own views about his gospel-that he wrote it himself and that it was published without his consent-can be extracted from Tertullian's polemical passages. ${ }^{63}$

57 Smith, Revisiting (see note 51), 99-118; idem, "Pneuma[tic Body]” (see note 56).

58 Dieter T. Roth, “Marcion's Gospel and Luke: The History of Research in Current Debate,” Journal of Biblical Literature 127 (2008): 513-527; Andrew Gregory, The Reception of Luke and Acts in the Period before Irenaeus (WUNT II 169; Tübingen, 2008), 192-210. See also BeDuhn, First New Testament (see note 1), 78-92.

59 BeDuhn, First New Testament (see note 1), 77. See also Klinghardt, “Markion vs. Lukas” (see note 6), 495-496; BeDuhn, “The Myth of Marcion as Redactor” (see note 12), 28-36.

60 Tertullian, Adversus Marcionem 4,43,7 (SC 456, 524,52-56 M./B.).

61 BeDuhn, First New Testament (see note 1), 88-90.

62 See above, note 3.

63 Vinzent, Marcion (see note 6), 94-101, referencing Tertullian, Adversus Marcionem 4,4,2 
Nonetheless, I would now agree with Klinghardt that "Lk 24,12 ist nicht sekundär in den kanonischen Text eingefügt worden, sondern in den vorkanonischen Mcn-Text. Diese Einfügung ist mithin ein integraler Teil der lk Redaktion”while reserving judgment on whether canonical Luke is an editorial expansion of Marcion's Gospel or of a common Vorlage. ${ }^{64}$ The question remains, however, whether it is justifiable to label this redactional program "anti-Marcionite," as Tyson, Vinzent, and Klinghardt do. ${ }^{65}$

\section{Theorizing Jesus' Body: $\varphi \alpha ́ v \tau \alpha \sigma \mu \alpha / \pi v \varepsilon \tilde{\mu} \mu \alpha$ and

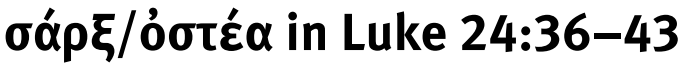

Of all the canonical gospels, Luke most explicitly theorizes the body of the resurrected Jesus. By way of contrast, when Jesus appears to the Eleven in Matthew, this occasions both doubt and worship (Matt 28:17), but there is no obvious focus on the nature or composition of his body. In Luke, when he appears to the Eleven and those with them (canonical Luke 24:36-43; cf. v. 33), the resurrected Jesus explicitly explains what his body is like, negating one specific term ( $\pi v \varepsilon \tilde{v} \mu \alpha)$ and

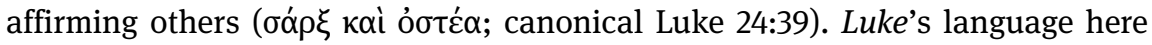
is significant in light of debates that took place in the second century and later about the eschatological resurrection, in particular whether or not it would be a resurrection of the flesh. This became a kind of litmus test for true Christianity, with those on both sides accusing one another of faulty exegesis and false teaching. ${ }^{66}$ Shelly Matthews correctly observes that "this is the only explicit reference to Jesus' fleshly resurrection in all of the canonical gospels, already a clue that Luke 24 may be a participant in a debate best placed in the third generation of Jesus followers." 67

(SC 456, 76,10-78,17 M./B.), and Tertullian, De praescriptione haereticorum 38 (CChr.SL 1, 218,1219,29 Refoulé).

64 Klinghardt, Das älteste Evangelium (see note 1), vol. 2, 1130 (emphasis original); see also Tyson, Marcion and Luke-Acts (see note 6), 108.

65 See above, note 6.

66 Outi Lehtipuu, Debates over the Resurrection of the Dead: Constructing Early Christian Identity (Oxford Early Christian Studies; Oxford, 2015).

67 Shelly Matthews, "Does Dating Luke into the Second Century Affect the Q Hypothesis?," in Gospel Interpretation and the Q-Hypothesis (ed. Heike Omerzu and Mogens Müller; International Studies on Christian Origins; London, forthcoming 2017), 8 (typescript). 
It is precisely here that Marcion's Gospel and canonical Luke are significantly different. In the descriptions of both the initial reaction of the Eleven and the response of Jesus, canonical Luke has $\pi v \varepsilon \tilde{v} \mu \alpha$ in vv. 37, 39 whereas Marcion's

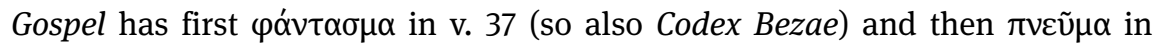
v. $39 .{ }^{68}$ If the point was to narrate the apostles' fear that they are seeing a ghost, only Marcion's Gospel (with Bezae's support) has the terminology correct, for $\pi v \varepsilon \tilde{u} \mu \alpha$ is never used for this kind of post-mortem apparition in classical or Hellenistic literature. ${ }^{69}$ If $\varphi \alpha ́ v \tau \alpha \sigma \mu \alpha$ is understood as a correction to address this terminological problem, the second uncorrected use of $\pi v \varepsilon \tilde{v} \mu \alpha$ would be difficult to explain; but the reconciliation of the two terms is, as Klinghardt notes, just what one would expect of a redactor. ${ }^{70}$ The question then becomes why canonical Luke has $\pi v \varepsilon \tilde{u} \mu \alpha$ twice and not $\varphi \alpha ́ v \tau \alpha \sigma \mu \alpha$, when clearly either intervention would be possible. We will return to this question below.

Although there are questions about the reconstruction of Jesus' reply (v. 38), Marcion's Gospel evidently lacked two important pieces in the following verse:

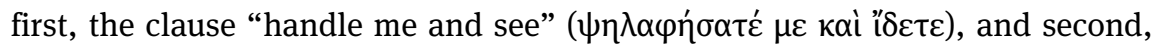
the word $\sigma \alpha \alpha \rho \xi$ as a feature of the resurrected Jesus' embodied state. Instead, Mar-

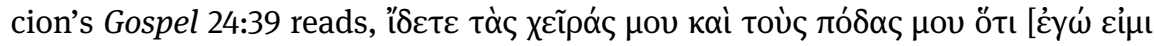

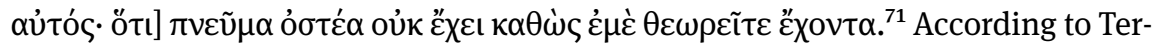
tullian, Marcion offered the strange interpretation that Jesus meant he did not have bones, just as a $\pi v \varepsilon \tilde{u} \mu \alpha$ does not have bones. ${ }^{72}$ This reading, which cannot be attributed to Marcion himself with any certainty, does seem to affirm $\pi v \varepsilon \tilde{v} \mu \alpha$ in a manner consistent with Marcion's view of Jesus, as we will see shortly.

To complicate matters further, the language found in canonical Luke's version of this pericope is also present in Ignatius, Ad Smyrnaios 3,1-2:

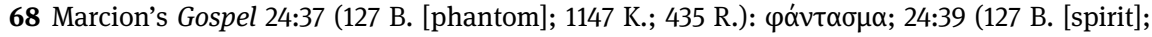
1147 K.; 435 R.): $\pi v \varepsilon \tilde{u} \mu \alpha$.

69 Smith, "Pneuma[tic Body]" (see note 56), 755-757, with literature; Terence Paige, "Who Believes in 'Spirit'? Пveṽ $\mu \alpha$ in Pagan Usage and Implications for the Gentile Christian Mission," Harvard Theological Review 95 (2002): (417-436) 420.

70 Klinghardt, Das älteste Evangelium (see note 1), vol. 2, 1151, wrongly assessing these terms as "unterschiedliche aber offensichtlich synonyme Begrifflichkeit."

71 Marcion's Gospel 24:39 (127 B.; 1147 K.; 435 R.): "See my hands and my feet, that [it is I myself; because] a spirit does not have bones as you see that I have." The bracketed words have divergent testimony in the heresiologists. BeDuhn and Roth include them, Roth indicating them as possible but in an indeterminate order; Klinghardt does not. For discussion, see BeDuhn, First New Testament (see note 1), 197; Klinghardt, Das älteste Evangelium (see note 1), vol. 2, 1152; Roth, Marcion's Gospel (see note 1), 183-184.

72 Tertullian, Adversus Marcionem 4,43,7 (SC 456, 524,54-526,61 M./B.) 


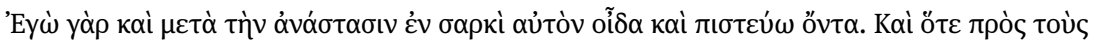

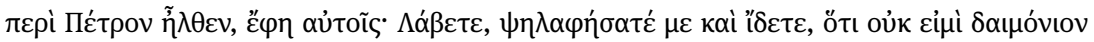

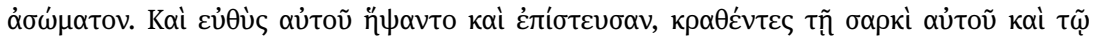
$\pi v \varepsilon v \dot{\mu} \mu \tau \tau{ }^{73}$
\end{abstract}

For I both know and believe that he was in the flesh even after the resurrection. And when he came to those of Peter's group, he said to them, “Take, handle me and see that I am not a bodiless demon." And immediately they touched and believed, having been mixed with his flesh and his spirit.

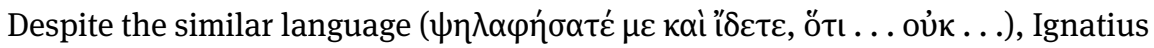
does not oppose $\sigma \alpha \dot{\rho} \xi \xi$ and $\pi v \varepsilon \tilde{u} \mu \alpha$ as canonical Luke does; and his concern to establish the true fleshly character of Jesus' body before and after Easter does not seem to be an issue for canonical Luke. ${ }^{74}$ In an earlier essay, I argued that the apologetic interest in Luke 24:36-43 was not anti-docetic, as is sometimes claimed, but instead anti-Pauline. ${ }^{75}$ Luke has the resurrected Jesus insist that he has flesh and bones, and therefore is not a spirit (24:39). In contrast, Paul argued that resurrection bodies are spiritual, that is, $\pi v \varepsilon v \mu \alpha \tau^{\prime}$ kos (1 Cor 15:44-46) and glorious (Phil 3:21), that Jesus the Last Adam became a life-giving spirit (1 Cor 15:45), and that flesh and blood cannot inherit the Kingdom of God, but must be transformed (1 Cor 15:50-53). In James Robinson's opinion, “[the] identification of the luminously resurrected Christ as the Spirit is in substance what Luke rejects as the false assumption that they had seen a ghost" the wrong word for ghost. Yet $\pi v \varepsilon \tilde{u} \mu \alpha$ seems precisely to be the problem: "where Paul can use $\pi v \varepsilon \tilde{v} \mu \alpha$ to describe the presence of the risen and exalted Christ," even the essence of his post-resurrection embodied state, "Luke's [ascensionPentecost] chronology forges a clear narrative distinction between the risen Jesus and the Spirit."77

The real question, however, is whether this section of canonical Luke theorizes the body of the resurrected Jesus as it does in order to refute Paul's views in the first century, or uses of Paul in the second, or indeed to refute Marcion himself. Read in its entirety, the chapter connects the authorization of the twelve male apostles-and their hermeneutical enlightenment by the resurrected Jesus-to the tangible resurrection appearances (canonical Luke 24:44-48). The

73 Ignatius, Ad Smyrnaios 3,1-2a (SC 10, 156 Camelot).

74 See e. g. Ignatius, Ad Smyrnaios 1,1-2 (155-156 C.).

75 Smith, “Seeing a Pneuma[tic Body]" (see note 56), 765-772.

76 James M. Robinson, “Jesus-From Easter to Valentinus (or to the Apostles' Creed),” Journal of Biblical Literature 101 (1982): (5-37) 13.

77 Smith, “Seeing a Pneuma[tic Body]” (see note 56), 771. 
flesh-and-bones, non-pneumatic nature of the Lukan resurrection appearances seems to be a vital ingredient, but without a specifically anti-docetic agenda, because the focus is on the nature of the appearances and not the embodiment of Jesus pre- and post-resurrection. Vinzent argues that Marcion's view of the body of Jesus is best described as "pneumatic corporeality," an idea probably derived from Paul's discussion of the resurrection body in 1 Cor $15{ }^{78}$ Referencing Paul's distinction between the "first man from the earth, of dust" and the "second man from heaven" (Marcion: "the second [is] the Lord from heaven,” v. 47), Vinzent observes that for Marcion "the hiatus between an earthly creature of ephemeral flesh and the heavenly Lord was unbridgeable."79 Likewise, Lieu states that "for Marcion the resurrected form of Jesus provided the key to his pre-resurrected form: 'I am the same' (Luke 24:39)." In addition, Marcion "used 'spirit' language both of the descended Christ and in a discussion of resurrection [1 Cor 15:47]."80 Tertullian says that Marcion held that Jesus descended from heaven, at the beginning of his earthly career, as a "saving spirit" (spiritus salutaris), but this is not part of the reconstructions of the beginning of Marcion's Gospel. ${ }^{81}$

If this is an accurate view of Marcion's Christology, then canonical Luke 24:39 could be seen as anti-Marcionite, but only in its negation of spirit and its focus on the flesh and bones of the resurrected Jesus, and not in the invitation to touch him. Evidently in Marcion's understanding, Jesus' spirit-body was not insubstantial-but it was not born in the normal human way and was not composed of normal human flesh. ${ }^{82}$ Lieu thinks "phantasma," Tertullian's favourite term for the body of Marcion's Jesus, "might be traced to Marcion himself, and it may point to the importance of Luke 24.37-9 in the argument." 83 This overlooks, however, the facts that $\pi v \varepsilon \tilde{v} \mu \alpha$ and $\varphi \alpha ́ v \tau \alpha \sigma \mu \alpha$ are not synonymous, and that Marcion's view of the pre- and post-resurrection corporeal continuity of Jesus would make $\varphi \alpha ́ v \tau \alpha \sigma \mu \alpha$ appropriate only after Jesus' death.

78 Markus Vinzent, “Christ's Resurrection: The Pauline Basis of Marcion's Teaching,” Studia Patristica 31 (1997): (225-233) 230-233; see also Markus Vinzent, "Der Schluss des Lukasevangeliums bei Marcion," in Marcion und seine kirchengeschichtliche Wirkung/Marcion and His Impact on Church History (ed. Gerhard May, Katharina Greschat, and Martin Meiser; TU 150; Berlin, 2002), (79-94) 85-86.

79 Markus Vinzent, Christ's Resurrection in Early Christianity and the Making of the New Testament (Farnham, 2011), 112. For Marcion's wording of 1 Cor 15:47, see Schmid, Marcion (see note 18), 108, 210, 327; BeDuhn, The First New Testament (see note 1), 241, 287; Tertullian, Adversus Marcionem 5,10,9 (SC 483, 214,73-75 Moreschini/Braun).

80 Lieu, Marcion (see note 5), 376.

81 Lieu, Marcion (see note 5), 371; Tertullian, Adversus Marcionem 1,19,2 (SC 365, 186,10 Braun).

82 Lieu, Marcion (see note 5), 372-376.

83 Lieu, Marcion (see note 5), 374. 
However, there is more at stake here in the emphasis on the flesh and bones of the resurrected Jesus. The command to "handle me and see" is actually less about proving what Jesus' body was like, or that after the resurrection he really was bodily present again with the apostles, and more about emphasizing the concrete connection between him and the Twelve. As Matthews explains,

Canonical Luke 24 sets out a programmatic statement on the connection of the appearance of the resurrected Jesus in the flesh to the exclusive authority of the eleven (soon-to-betwelve) apostles/witnesses. This connection is underscored in the inaugural speeches of both Peter (Acts 2:31-32) and Paul (13:31,37) in which assertions that Jesus' flesh was not corrupted through the process of death and resurrection are closely linked to authorization of the twelve as exclusive witnesses to that resurrection. ${ }^{84}$

At this point, the odd idea in Ignatius, Ad Smyrnaios 3,2 about those who touched the resurrected Jesus "being mixed [or mingled] with his flesh and spirit"

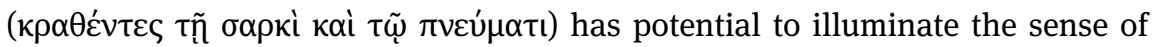

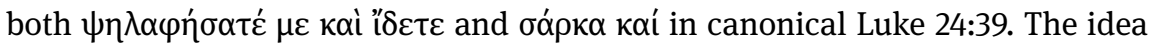

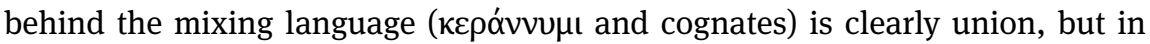
other instances where Ignatius refers to flesh and spirit together, the implication is incorporation into an ordered hierarchical relationship. ${ }^{85}$ This is already evident in the following line:

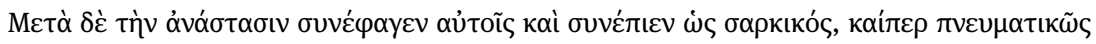

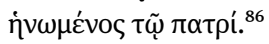

And after the resurrection, he ate and drank with them as a fleshly [being] even though [he was] spiritually united with the Father.

According to William Schoedel, "Eph. 5.1 offers the best commentary on the meaning of the word 'mingled' [in Smyrn. 3.2]." 87 That text reads as follows:

84 Matthews, "Dating Luke" (see note 67), 9.

85 A similar observation is made by Travis W. Proctor, "Bodiless Docetists and the Daimonic Jesus: Daimonological Discourse and Anti-Docetic Polemic in Ignatius' Letter to the Smyrnaeans," Archiv für Religionsgeschichte 14 (2013): (183-204) 191-192, who however fails to account for the language of mixing and its connection in the immediate context with language of ecclesial hierarchies.

86 Ignatius, Ad Smyrnaios 3,3 (156 C.).

87 William R. Schoedel, Ignatius of Antioch: A Commentary (Hermeneia; Philadelphia, 1985), 227. 


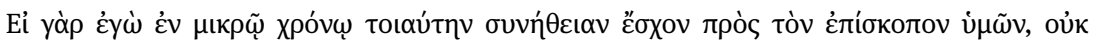

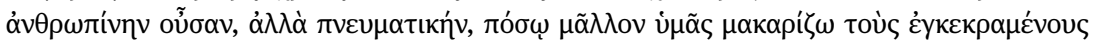

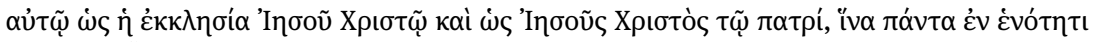
$\sigma u ́ \mu \varphi \omega v \alpha \tilde{n}_{n} ; 8$

For if I, in so short a time, have had such fellowship with your overseer-not human fellowship, but spiritual-how much more do I call you blessed, who are mixed with him, as the congregation [is] with Jesus Christ and as Jesus Christ [is] with the Father, so that all things might be harmonious in unity?

Schoedel explains that "mixing" with the overseer is a musical metaphor, referring to the blending of voices in harmony, as oú $\mu \varphi \omega v \alpha$ suggests. ${ }^{89}$ The musical language is missing from Ad Smyrnaios 3,2, however, as it also is from Ad Magne$\operatorname{sios} 13,2$ :

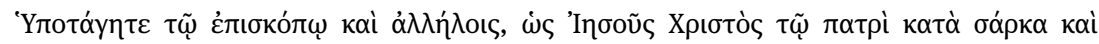

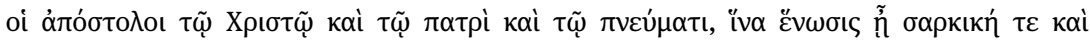
$\pi v \varepsilon v \mu \alpha \tau \iota \kappa \eta ் .90$

Submit to the overseer and to one another, as Jesus Christ [submitted to] the Father according to the flesh, and the apostles to Christ and to the Father and to the Spirit, so that the union might be both fleshly and spiritual. ${ }^{91}$

For Ignatius, there is a fleshly component to the spiritual union that is the basis of the ecclesial hierarchy: this fleshly-spiritual union between the congregation and its overseer originates in the fleshly-spiritual union between the resurrected

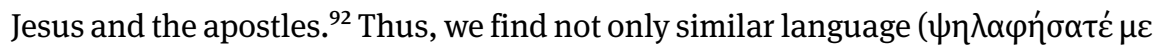

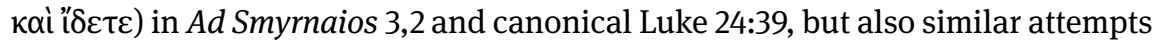
to restrict authorization to those who had fleshly contact with the resurrected Jesus. A mid-second-century date for the letters of Ignatius would leave open the possibility that the author was inspired both linguistically and theologically by

88 Ignatius, Ad Ephesios 5,1 (SC 10, 72 Camelot).

89 Schoedel, Ignatius (see note 87), 55.

90 Ignatius, Ad Magnesios 13,2 (SC 10, 106 Camelot).

91 Similar examples may be found in Ignatius, Ad Magnesios 1,2 (94 C.); Ad Romanos praef. 1 (SC 10, 125 Camelot); Ad Smyrnaios 1,1 (154 C.); Ad Polycarpum 5,1 (SC 10, 174 Camelot).

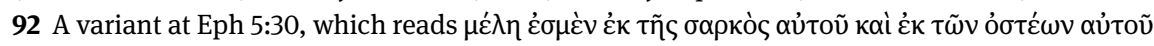

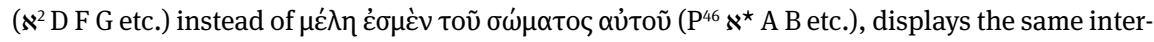
est and might possibly have been influenced by canonical Luke 24:39; cf. the critical apparatus of NA ${ }^{28}$ (Barbara and Kurt Aland et al., eds., Novum Testamentum Graece [28th rev. ed.; Stuttgart, 2014], 600). I thank Shelly Matthews for pointing me to this reading. 
canonical Luke 24:39, particularly because the idea of mixing or mingling seems more developed than what is found in Luke. ${ }^{93}$

This focus on the authorization of the eleven apostles continues in the final section of canonical Luke. Evidently canonical Luke 24:44-53 are unattested in Marcion's Gospel, except for the command "to preach . . . to all nations" (v. 47). ${ }^{94}$ In these verses, the resurrected Jesus opens the mind (voũc, v. 45) of the apostles to understand the Scriptures, and explains to them how the Law, the Prophets, and the Psalms point to the suffering and rising of the Messiah (vv. 44-46). ${ }^{95}$ Given that Marcion purportedly claimed in his Antitheses that the true gospel was being "interpolated by upholders of Judaism" through combination with "the law and the prophets," it is surprising that both Tertullian and Epiphanius pass over this lacuna in silence. ${ }^{96}$ Incidentally, Paul is excluded from this enlightenment because his experience of the resurrected Jesus is visionary and not based in tangible fleshly contact; however, as Klinghardt points out, there are significant parallels between the hermeneutic in this section of Luke 24 and that in Paul's speech before Agrippa and Festus in Acts $26 .{ }^{97}$ Further, the Emmaus road encounter (canonical Luke 24:13-35) evidently was in Marcion's Gospel, and contained wording about the Israel's expected redemption (v. 21), the disciples' slowness to understand (v. 25), and the Messiah's suffering (v. 26). ${ }^{98}$ However, the references in this section to the interpretation of the Scriptures (canonical Luke 24:27.32b) are unattested and quite probably were not in Marcion's Gospel. ${ }^{99}$

93 I find convincing the arguments for dating the letters of Ignatius to the 140s put forward by Timothy D. Barnes, “The Date of Ignatius,” Expository Times 120 (2008): (119-130) 123-125, especially the emphasis on the touchable Christ as polemic against Ptolemaeus. Vinzent's view that

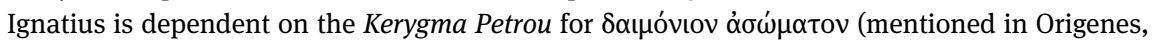
De principiis 1, praef. 8 [SC 252, 86,147-88,172 Crouzel/Simonetti]) is problematic on several counts. See Vinzent, Christ's Resurrection (see note 79), 147-155.

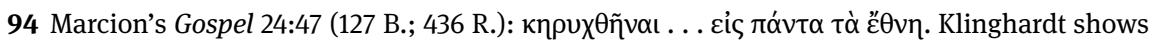
the entire section Marcion's Gospel 24:44-49 as unattested including these words from v. 47 (1147 K.), and views canonical Luke 24:44-49 in its entirety as a post-Marcionite redactional creation: Klinghardt, Das älteste Evangelium (see note 1), vol. 2, 1156-1158.

95 See Matthew W. Bates, "Closed-Minded Hermeneutics? A Proposed Alternative Translation for Luke 24:45," Journal of Biblical Literature 129 (2010): 537-557, who argues that it is the mind (voṽ ) of the Scriptures that the risen Jesus opens for the apostles (canonical Luke 24:45).

96 Tertullian, Adversus Marcionem 4,4,4 (SC 456, 78,30-80,31 M./B.): ipsum est quod Marcion per Antitheses suas arguit ut interpolatum a protectoribus Iudaismi ad concorporationem legis et prophetarum.

97 Klinghardt, Das älteste Evangelium (see note 1), vol. 2, 1156.

98 Marcion’s Gospel 24:13-35 [passim, with variations] (126-127 B.; 1131 K.; 435 R.).

99 Marcion's Gospel 24:27 [unattested] (435 R.); [unattested and probably not in Marcion's Gospel] (127 B.; 1131 K.). Marcion’s Gospel 24:32 [unattested] (435 R.); [unattested and probably not in 
Despite the convergence in canonical Luke 24 of several redactional themes that could be considered "anti-Marcionite"-namely, the insistence on Jesus' fleshly body, the refusal of $\pi v \varepsilon \tilde{u} \mu \alpha$ and $\varphi \alpha ́ v \tau \alpha \sigma \mu \alpha$ as appropriate terms for Jesus' post-resurrection state, and references to the Scriptures and to the authorization of the Twelve-Marcion is not necessary to make sense of the apologetic arguments of canonical Luke $24 .^{100}$ First, as the parallels with Ignatius show, the focus on fleshly contact with Jesus need not be intended to refute Marcion's Christology, but can be explained as a strategy to restrict primary and original authorization to the Twelve and thereafter to those who can be connected with them. Even this might be viewed as anti-Marcionite. However, it is important to note that this restricting tendency can already be seen in Marcion's Gospel 24:6-7, where (if we are still right to support the priority of Mark!) the commission given to the women

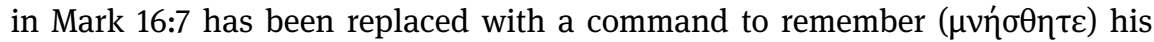
teaching. ${ }^{101}$ Second, and along similar lines, the negation of $\pi v \varepsilon \tilde{v} \mu \alpha$ makes sense as a rejection of Pauline views about the resurrected Jesus, rather than Marcionite views of Jesus' body, even if Lieu is correct that Marcion had a spirit-Christology. ${ }^{102}$ Robinson was right that Luke resisted Paul's notion that Jesus rose as the Spirit (1 Cor 15:45; 2 Cor 3:17), but again, this redactional interest can be better explained in the second century than in the first (as Robinson presumably supposed). ${ }^{103}$ In addition, Paul did not distinguish his own encounter with the res-

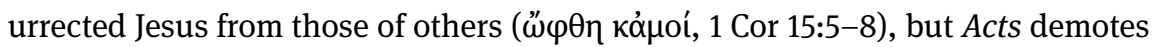
his experience to a post-ascension vision (Acts 9:1-9), which puts it in a different category of authorization and revelation than that experienced by the Twelve.

Marcion's Gospel] (127 B.); [unattested and possibly in Marcion's Gospel, except for tos Singet

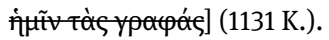

100 Klinghardt, Das älteste Evangelium (see note 1), vol. 1, 171 even suggests that Marcion himself knew and disapproved of canonical Luke 24, and had it in mind when he impugned the “interpolated gospel” (Tertullian, Adversus Marcionem 4,4,4 [SC 456, 78,30-80,31 M./B.]; see above, note 94).

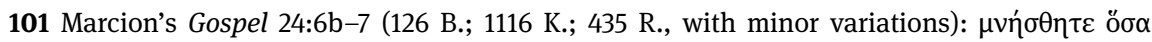

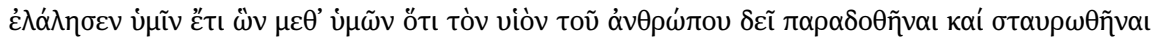

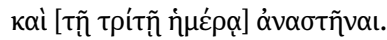

102 Lieu, Marcion (see note 5), 370-371.

103 Robinson, "Jesus-From Easter" (see note 76), 12-13. 


\section{Conclusion}

While a modest case has been made here for the priority of Marcion's Gospel 24 over canonical Luke 24, it is based partly on the view that it is unlikely, given the shape and contents of Marcion's Gospel as reconstructed, that Marcion's Gospel originated as an abridged version of canonical Luke, mainly because of the lack of a coherent editorial agenda. Admittedly, the additional evidence just offered for the view that canonical Luke 24 is the later text is suggestive rather than conclusive. The correspondence between Marcion's Gospel as reconstructed and the shorter Western readings-even if they are taken generally to be original-can be explained in a variety of ways. Similarly, the emphasis on the fleshly, non-pneumatic mode of the resurrection appearances in canonical Luke 24 could possibly be seen not as later and secondary to Marcion's Gospel, but as original and falling victim to Marcion's mutilation of canonical Luke. However, as shown above, at least two features of v. 39 problematize this view, namely, the lack of correspondence between $\pi v \varepsilon \tilde{v} \mu \alpha$ and $\varphi \alpha ́ v \tau \alpha \sigma \mu \alpha$, and the presence of material that

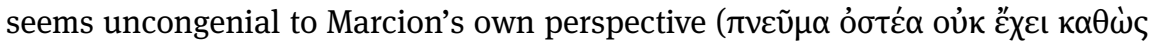

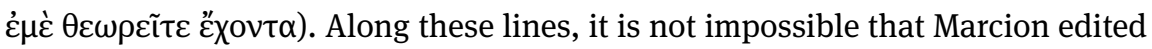

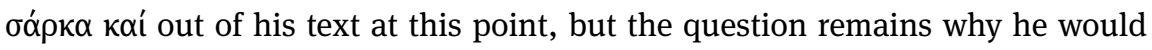
have left the rest of the verse as it is. Further, while a coherent set of interests seems to set canonical Luke 24 material apart from what can be reconstructed for Marcion's Gospel 24, this needs to be tested in a more detailed way. Are there elements of Lukan style and vocabulary in material unique to canonical Luke 24 (i. e. not found in Marcion's Gospel 24), such that the posteriority of this material can be challenged? Or, are there commonalities in style and vocabulary between canonical Luke 24 material and canonical Luke material elsewhere in the gospel, for example in the birth narratives, such that a coherence of canonical Luke material can be demonstrated for the whole of Luke? These questions unfortunately are beyond the scope of this short contribution.

In my opinion, the evidence just considered suggests that canonical Luke 24 is the later form of the chapter, and Marcion's Gospel 24 the earlier, but there are still reasons for thinking that the later edition was not composed in direct opposition to the teachings of Marcion. Instead, the text could equally have been addressing problems more chronologically proximate to a (moderately) revised date for the final composition of Luke. Thus, eliminating Marcion as both the polemical target of the final canonical form of Luke 24 and the originator of the shorter form of the chapter means that the two forms of the Gospel can be seen as different recensions of the same text. Therefore, it is worth reconsidering in detail the view, mentioned above, that canonical Luke and Marcion's Gospel share a common Vorlage. In this case, the priority of Marcion's Gospel would mean that 
there would be a place for Marcion's Gospel (or at least its Vorlage) in the Synoptic Problem, but not as the immediate source text for canonical Luke, nor indeed at the very beginning supplanting Mark (or $Q$ ) as "the earliest gospel."

Acknowledgement: A first draft of this paper was read at the annual meeting of the Canadian Society of Biblical Studies, Calgary, 30 May 2016. I also wish to thank Shelly Matthews, who kindly read and commented on the earlier draft, and generously shared with me her own forthcoming work on Luke 24. 